\title{
Potential Fraud in The Primary Healthcare
}

\author{
Nizar Fathurrohman*, Arlina Dewi*
}

* Author Correspondent: nizar.fathurrohman@gmail.com

* Master of Hospital Management, Postgraduate Universitas Muhammadiyah Yogyakarta, Yogyakarta, Indonesia

\begin{tabular}{lll}
\hline I N D E X I N G & A B S T R A C T \\
\cline { 1 - 3 } Keywords: & This study discusses of potential fraud at the primary healthcare. Fraud is more often associated with \\
Fraud; & secondary healthcare, namely hospitals, so that fraud in primary healthcare rarely supervises. Premi \\
Primary Healthcare; & of JKN around 38.5 trillion and estimating the potential fraud of around $5 \%$ will disappear 1.8 trillion \\
Audit; & per year. This research used qualitative methods with phenomenological design, as the data are \\
Human Resource; & collected using in-depth interview and observation techniques. The number of respondents in this \\
Capitation; & research were 3 public healthcare and 2 private healthcare in X regency. The results showed potential \\
& fraud in primary healthcare related to human resources (HR), management of health service, \\
& leadership policies, management of capitation funds and operational audits.
\end{tabular}

\begin{abstract}
Kata kunci:
Fraud;

FKTP;

Audit;

Sumber Daya Manusia;

Penelitian ini membahas potensi fraud pada fasilitas kesehatan tingkat pertama (FKTP). Fraud lebih sering di kaitkan dengan fasilitas kesehatan tingkat lanjut (FKTL) yaitu rumah sakit, sehingga fraud di FKTP jarang ada yang mengawasi. Premi BPJS kesehatan sekitar 38.5 triliun dan diperkirakan potensi terjadinya fraud sekitar 5\% maka akan hilang sebesar 1.8 triliun per tahun. Penelitian ini menggunakan metode kualitatif dengan desain fenomenologis, pengumpulan data menggunakan wawancara mendalam. Responden penelitian adalah 3 kepala puskesmas dan 2 kepala klinik swasta di kabupaten X. Hasil penelitian menunjukan potensi fraud pada FKTP bekaitan dengan sumber daya manusia (SDM), manajemen pelayanan kesehatan, kebijakan kepemimpinan, pengelolaan dana kapitasi dan audit operasional.
\end{abstract}

(C) 2018 JMMR. All rights reserved

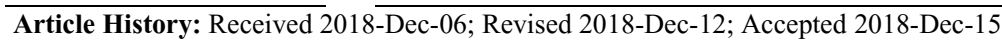

\section{INTRODUCTION}

The implementation of national health insurance in Indonesia began on January 1, 2014. National health insurance was organized by Badan Penyelenggara Jaminan Sosial (BPJS). This health insurance aims to facilitate access to health services needed and the ease of access is also supported by the quality and quality of good service. Gradually until 2019 the entire community will be covered by a Universal Health Coverage. ${ }^{-}$

Universal Health Coverage (UHC) is a concept dealing with health service reform covering all communities in terms of accessibility and equity of health services, quality and comprehensive health services that cover preventive, promotive, curative to rehabilitative services and reduce financial limitations to obtain health services for every resident. $\stackrel{2}{-}$

One strategy for achieving UHC is by the existence of the National Social Security System (SJSN), in which there is a National Health Insurance (JKN) held using a mandatory social health insurance mechanism. National Health Insurance (JKN) is a guarantee that is used to ensure participants get the benefits of health care and protection for the fulfillment of basic health needs, which are given to everyone who has paid contributions or fees paid by the Government. In an effort to realize the UHC organized by the BPJS, there must be a number of problems, including advocacy and JKN socialization, institutional policies, program transformation, participation, referral systems, health facility infrastructure, HR, capacity building, financing, the risk of JKN Fraud, the impact of JKN on utilization, provider satisfaction and participants. ${ }^{3}$

Health care is an important factor in improving the health and well-being of every person in the world. Everyone has the right to obtain health services and the government is responsible for the availability of all forms of quality, safe, efficient and affordable health efforts by all levels of society. . $^{-}$

One such effort is to increase the availability and equity of basic health care facilities such as health centers in each region increasing public awareness of health, will lead to demands for improved health services. One effort to anticipate this situation is to maintain the quality of service, so that continuous efforts need to be made to find out the weaknesses and shortcomings of health services. The increasing demand of the community for the quality of health services, the function of health services needs to be improved to provide patient satisfaction. Quality of service 
is a form of consumer (patient) assessment of the level of service received with the level of service expected. -5

There are many tariffs that are inadequate in the allocation of costs that are needed, so that the opportunity for the emergence of services that are below the standard and affect the quality of services, the availability of drugs and other supporting facilities and facilities make the process of service to the community not optimal. With these problems the possibility of fraud is large. ${ }^{6}$

Capitation rates are the amount of early monthly payments paid by the BPJS to Primary healthcare based on the number of registered participants, regardless of the type and amount of health services provided. The health services that are funded by capitation are service administration, promotive and preventive services, medical examinations, and consultations, non-specialist medical actions both operative and non-operative, medical services and consumables including pills and condoms for family planning services and diagnostic testing first level laboratory.?

JKN participants have the following rights and obligations:

Rights of Participants

1. Get the participant card as valid proof to obtain health services

2. Obtain benefits and information about rights and obligations and health service procedures in accordance with applicable regulations

3. Get health services in health facilities in collaboration with BPJS health
4. Submitting complaints / complaints, criticisms and suggestions verbally or in writing to the BPJS health office

Obligations of participants

1. Registering himself as a participant and paying contributions in accordance with applicable regulations

2. Report changes in participant data, whether due to marriage, divorce, death, birth, change of address or move to a first-rate health facility

3. Keep the card from being damaged, lost or exploited by unauthorized people

4. Comply with all provisions and procedures for health services

In the JKN era, the public healthcare which organizes public health efforts (UKM) and individual health efforts (UKP) and cooperates with BPJS to become a level health care provider first for JKN participants. As the executor of the gatekeeper. The implementation of the concept of the gatekeeper aims to improve the quality of health services in the advanced level of health facilities that have previously been handled first by the public healthcare thereby reducing the workload of the hospital. -

Fraud health services are the dominant factor that causes high health costs in the United States. The Federal Bureau of Investigation (FBI) estimates that around 3-10\% of total health costs are lost due to fraud or estimated at 75 dollars to 250 dollars in 2009.4 Fraud cases after we calculated based on Premi BPJS around 38.5 trillion and estimating the potential fraud around 5\%, 1.8 trillion will be lost per year. ? $^{-}$

Tabel 1. Forms of fraud that have the potential to be carried out in health services according to National Health Care-Anti Fraud Association (NHCAA, 2012)

\begin{tabular}{|c|c|}
\hline Action & Operational definition \\
\hline Keystroke Mistake & Errors in typing the diagnosis code, procedures that can result in claims that are bigger or smaller \\
\hline Upcoding & $\begin{array}{l}\text { Incorporate billing claims on the basis of inaccurate code, which is a more complex diagnosis or } \\
\text { procedure or more use of resources to produce a claim value higher than it should be. }\end{array}$ \\
\hline Phantom billing & Bill for services that have never been given \\
\hline $\begin{array}{l}\text { Service Unbundling or } \\
\text { Fragmentation }\end{array}$ & $\begin{array}{l}\text { Bill several procedures separately which should be billed together in the form of a service package to } \\
\text { get a bigger claim in one episode of care }\end{array}$ \\
\hline Cancelled services & Billing of drugs, procedures or services that were previously planned but later canceled \\
\hline No Medical Value & $\begin{array}{l}\text { Billing for services that do not improve the patient's degree of recovery or even aggravate the } \\
\text { condition of the patient, especially those without evidence of scientific efficacy }\end{array}$ \\
\hline Standar of Care & Service billing that does not meet the applicable patient qualification and safety standards \\
\hline
\end{tabular}


Tabel 1. (Continued) Forms of fraud that have the potential to be carried out in health services according to National Health Care-Anti Fraud Association (NHCAA, 2012)

\begin{tabular}{ll}
\hline \multicolumn{1}{c}{ Action } & Operational definition \\
\hline Self Referral & Health care providers who refer to themselves or their colleagues to provide services, generally \\
accompanied by money or commission incentives & Bill the cost of care for a room whose treatment class is higher than what the patient actually uses \\
Type of Room Charge & Bill the procedure using the maximum average operating time instead of the actual duration of \\
Time in OR & operation. Especially if the duration of the operation is shorter than the average \\
& Using an electronic medical record system and modeling patient profile specifications that are formed \\
Cloning & $\begin{array}{l}\text { automatically by copying the profiles of other patients with similar symptoms to show the impression } \\
\text { that all patients have a complete examination }\end{array}$ \\
Bill the cost of care when the patient is not in the hospital or increase the number of days to increase \\
the claim.
\end{tabular}

Fraud actions carried out by health care providers in primary healthcare include:

- Use capitation funds not in accordance with the rules

- Manipulate claims on non-capitation paid services

- Receive commissions for referrals to secondary healthcare

- Withdraw fees from participants who should have been guaranteed in capitation and / or noncapitation fees in accordance with the standard set rates

- Conduct patient referrals that are not appropriate for certain benefits

- Deliberate transfer of participants to a particular primary healthcare

- Not reporting changes in resources that affect capitation payments. $\underline{10}$

Primary healthcare, especially public healthcare, are the spearhead of health services in Indonesia, since the JKN program was launched, public healthcare is required to partner with BPJS. Other healthcare such as private clinics may partner with BPJS after fulfilling the applicable requirements. BPJS has the authority to make agreements with health facilities regarding the amount of payment of health facilities that refers to the standard rates set by the government. BPJS also has the authority to make or stop work contracts with health facilities. $\frac{11}{}$

The indications and JKN fraud incidents at the Primary healthcare Semarang include extending hospitalization days \& forgery of medical record data: Fraud of Financial Reports in the form of Assets / Revenue Overstatement by falsifying transaction evidence, \& NonFinancial fraud manipulation of internal audit. While incidents of fraud committed by BPJS participants duplicate the function of cards by BPJS participants, including in misuse of Inventories and Other Assets or Misuse. In addition there is a dispute between the BPJS and FKTP, such as the late capitation payment of the FKTP by BPJS. $\frac{12}{-}$

The implementation of JKN, especially those carried out by the primary healthcare, has been going on for a long time, so it is necessary to discuss the potential fraud of primary healthcare held in $\mathrm{X}$ regency.

\section{RESEARCH METHOD}

This research used qualitative methods with phenomenological design. Qualitative approach is a process of research and comprehension based on methodology which investigates a social phenomenon and human problem. Research is intended to understand the phenomenon of what is experienced by the subject of research such as behavior, perception, motivation, actions, etc., holistically and by means of descriptions in the form of words and language, in a special context that is natural and by utilizing various methods, so that it is expected that the description of the phenomena that appear in the field can be interpreted with deeper meaning and content.

This study discusses the potential fraud in the primary healthcare, the number of respondents in this research were 3 head of public healthcare and 2 head of private healthcare in $\mathrm{X}$ regency, each respondent was interviewed at different times.

Documentation is made in in-depth interview and it might be in form of a recorded interview, notes, and so on, all of which support the obtained data. Methods of data collection conducted by researchers is by in-depth interviews. Interviews are talks that have goals and are tackled with some informal questions. Interviews aimed at obtaining information from research responden. Researchers conducted interviews by exploring the feelings, perceptions and thoughts of the study responden. The result 
of interviews with responden are also used as support data proposed by the researcher.

\section{RESULT AND DISCUSSION}

The results showed the potential of fraud at the primary healthcare in $\mathrm{X}$ regency was the management of human resources (HR) potential to occur fraud in the weak performance appraisal, poor HR personality and low HR skills. Health service procedures have the potential for fraud with discrimination, lack of facilities and infrastructure, weak of work systems and health service procedures that have not well. Leadership policies that are not accordance with the rules.

The audit system has the potential to cause fraud if it does not have unclear funds and rules. Capitation funds have the opportunity to cause fraud with high capitation residual funds and does not optimize capitation funds to get the maximum benefit for JKN participants.
Tabel 2. Potential fraud at the primary healthcare

\begin{tabular}{|c|c|c|}
\hline No. & Category & Interpretation \\
\hline 1. & $\begin{array}{l}\text { Human resources } \\
\text { management }\end{array}$ & $\begin{array}{l}\text { Performance } \\
\text { assessment } \\
\text { Personality } \\
\text { Skill }\end{array}$ \\
\hline 2. & $\begin{array}{l}\text { Health service } \\
\text { procedures }\end{array}$ & $\begin{array}{l}\text { Discrimination } \\
\text { Infrastructure } \\
\text { Work system } \\
\text { Service procedure }\end{array}$ \\
\hline 3. & Leadership & Policy \\
\hline 4. & Audit & $\begin{array}{l}\text { Rules } \\
\text { Cost }\end{array}$ \\
\hline 5. & Fund & $\begin{array}{l}\text { Capitation funds } \\
\text { Remaining funds }\end{array}$ \\
\hline
\end{tabular}

Perceived pressure is defined as the motivation that leads the perpetrator to engage in unethical behaviors. Such pressure does not have to be real, if the perpetrators believe they are being pressured, it can lead to fraudulent behavior. ${ }^{?}$

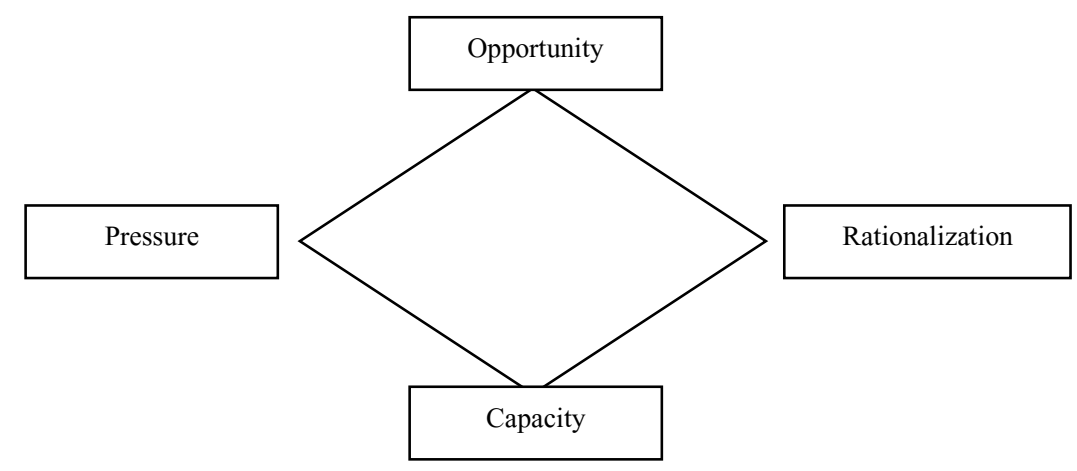

Figure 1: Elements of Fraud Diamond

Incentives or pressure to commit fraud. The pressure felt by fraud perpetrators is seen as a need, along with factors that can cause pressure

1. Strong level of competition or saturation accompanied by reduced income or profit

2. Steer clear of criticism because of lower income levels

3. Covering errors

A person's position or function within a company may give him or her the ability to create or exploit an opportunity for fraud not available to others. Observable traits related to individuals' capacity to commit fraud. Those threats include:
1. The ability to do or take advantage of opportunities to commit fraud where these functions are not shared by others

2. Intelligence to understand and exploit internal control weaknesses for the benefit of others

3. Strong belief that fraud events will not be detected or the ability to mislead others

4. The ability to influence others to help get involved in or hide fraud events

5. The ability to influence others to help get involved in or hide fraud events

6. The ability to lie and divert confidence

7. Manage stress well because cheating is usually carried out on an ongoing basis 
Table 3. Findings Aspects of KPK Investigation in Utilizing Capitation Funds in Public Healthcare 14

\begin{tabular}{|c|c|}
\hline Regulation & Supevision \\
\hline $\begin{array}{l}\text { 1. Rules for the distribution of medical services and } \\
\text { operational costs have the potential to cause moral hazard } \\
\text { and impropriety } \\
\text { 2. Not yet regulating more residual capitation mechanisms } \\
\text { 3. The rules do not accommodate the needs of the FKTP }\end{array}$ & $\begin{array}{l}\text { There is no supervision budget for capitation funds in the } \\
\text { regions. } \\
\text { There is no monitoring and control tool for capitation } \\
\text { funds by BPJS }\end{array}$ \\
\hline $\begin{array}{l}\text { Fund } \\
\text { 1. Potential fraud for permitting the transfer of } \\
\text { Contribution Assistance Participants (PBI) from the } \\
\text { public to the private FKTP } \\
\text { 2. The overall change in the quality of services at the } \\
\text { Puskesmas has not been seen in a real way. }\end{array}$ & $\begin{array}{l}\text { Human Resources } \\
\text { 1. Weak understanding and competence of health workers in } \\
\text { carrying out regulations } \\
\text { 2. The verification process for the eligibility of participation } \\
\text { in FKTP has not gone well } \\
\text { 3. The implementation of a tiered referral mechanism has } \\
\text { not gone well } \\
\text { 4. Potential FKTP officers become perpetrators of fraud } \\
\text { 5. Public officers are vulnerable to being victims of } \\
\text { 6. Uneven distribution of health workers. }\end{array}$ \\
\hline
\end{tabular}

Human resources are the potential in human beings to realize their role as adaptive and transformative social beings who are able to manage themselves and all the potential around them to achieve the welfare of life in a balanced and sustainable order. Competent and quality human resources are needed in an effort to support productivity and activities so that the goals of the country or organization can be achieved. $\frac{16}{}$

Human resource skills become an important role in the management of community services, quality human resources is one of the important factors for the survival and progress of the organization, because it can directly affect the performance of the organization itself. The main focus of human resource management is contribute to the success of the organization. The key to improving organizational performance both public and private healthcare is to ensure that human resource activities support the organization's efforts that focus on productivity, service and quality. HR performance appraisal plays an important role in improving organizational performance. Performance appraisal is very important, especially services provided by HR that support of holistic health services. $\frac{17}{}$

Reward is one tool to increase work motivation, aiming to improve its performance. Punishment is an unpleasant act, in the form of punishment or sanction given to employees, that given to employees consciously when a violation occurs, it is hoped that it does not repeat again. $\frac{18}{-}$
Opportunities for fraud can be detrimental to JKN participants in terms of limiting health services and access including discrimination in health services for participants and non-participants, limited basic service facilities that should be obtained by participants, poorly managed work systems that harm JKN participants and service procedures make it difficult for participants to get health services. $\frac{19}{}$

Weak internal controls facilitate fraud to grow and develop rapidly in addition to the inadequate external monitoring system that makes detection of fraud not optimal. Two mechanisms that organizations can use to prevent fraud. The first is to implement pre-employment screening; the second is to implement mechanisms (internal controls) during the course of employment. The system of internal controls is clearly necessary for businesses' success, which is critical for businesses to have some types of controls in place to eliminate the opportunity element. $\underline{22}$

Discrimination is an unfair and unbalanced treatment carried out to distinguish between individuals or groups, based on something, usually categorized or distinctive attributes. $\frac{10}{}$ Theoretically, discrimination can be done through policies to reduce, destroy, conquer, move, protect legally, creating cultural pluralism and assimilating other groups. In this case, differentiating service and type time from JKN participants includes one example of discrimination. $\underline{23}$

Inadequate facilities and infrastructure lead to fraud, for example JKN participants who are sent to private 
laboratories for examiners. Public healthcare facilities must be standard in providing minimal health services. Facilities that must be provided are general examination rooms, action rooms, $\mathrm{MCH}$ rooms, family planning and immunization, dental and oral health rooms, breastfeeding rooms, health promotion rooms, pharmacy rooms, labor halls, laboratories, etc. ${ }^{24}$ While the facilities that must be equipped with private healthcare are waiting/registration rooms, consultation rooms, administration rooms, medicine rooms, action rooms, ASI rooms, bathrooms and etc..$\underline{25}$

Internal control is the use of all organizational or company resources to improve, direct, control and supervise various activities with the aim of ensuring that the goals of the organization or company are achieved. For this reason, it is necessary to develop a good system so that the goal of the clinic or puskesmas can be achieved. Companies must create procedures and policies so that every activity carried out in the company must go through a system designed to be able to direct, control and supervise a series of activities. So that company services can be efficient and effective. This is expected to make it easier for the public or JKN participants to get health services..$\underline{26}$

Prevention of fraud can be done by activating internal controls. Active internal control is usually the most widely applied form the internal control. It is like a fence that prevents thieves from entering people's yards. Like a fence, however, a strong fence can still be penetrated by clever and courageous fraud person. $\underline{27}$

The primary healthcare using the capitation system, that is a method of payment for health services where the primary healthcare receives funds from a number of participants per period of time for a predetermined service. Capitation funds are used for budgeting, implementation, and administration. Capitation fund accountability by the primary healthcare. $\frac{28}{}$

Frauds that often occur include misuse of interests, bribery, illegal acceptance, corruption, and etc. The fraud of the financial sector does not only occur in the private sector but also occurs in the public sector or government, which is certainly detrimental to society and the state. $\underline{29}$

The fraud person believe that the action is not a fraud but that is indeed their right, sometimes the person feels that he has contributed to the organization. The capitation management of the public healthcare enables fraud to occur from an element of rationalization to fraud, including:

1. Add points for public healthcare officers who doing multiple tasks
2. Using the operational assistance fund of the public healthcare which is also funded by the government operational and regional budget funds.

3. Utilizing the remaining capitation funds into service funds..$\underline{30}$

Management of the remaining funds in the primary public healthcare is still unclear, the residual funds are increasing every year but there are no clear management regulations.

Utilization of capitation funds is still constrained by the number of health centers that do not carry out the planning process in accordance with the mechanism in force. The constraints faced by the puskesmas are limited resources that understand planning, low commitment from the head and puskesmas personnel to planning, not yet maximized coaching support from the Health Office and the absence of applicable implementation instructions in the puskesmas. Technically, the obstacle in the preparation of budget planning for capitation funds is the existence of the same designation from two budget sources, namely JKN and BOK capitation which can finance promotive and preventive efforts which can lead to potential overlapping of funds allocation. Another obstacle is limited capitation funds, the potential for remaining budgets to accumulate and existing regulations do not allow to divert the portion of the budget. $\frac{31}{}$

The operational funds that should be used for healthcare service needs are not used properly. A good healthcare should be managed transparently, independently, accountably, responsibly and fairly so that financial performance can be achieved in accordance with the vision and mission. $\frac{32}{-}$

Leadership is part of management that occupies strategic positions in the system and hierarchy of work and responsibility in an organization. $\frac{33}{3}$

Fraud risk can be classified into three categories, namely:

1. Risks related to the corporate environment, which include leadership style, incentive systems, overall corporate ethics, industrial pressure, and working relationships with others.

2. Risks related to the offender, such as any financial or work related pressures, opportunities to commit fraud and rationalization.

3. Risks related to financial records and accounting practices. $\frac{34}{4}$ 
An attitude or morally acceptable rationalization needs to occur before fraudulent behavior emerges. It is important to acknowledge that fraud perpetrators sometimes do not view their actions as unethical; they merely justify their actions as ethical before fraud takes place. $\stackrel{21}{-}$ Low income and sustained earnings are behind the emergence of rationalization.

The leadership policy in formulating work programs and budgets plays an important role in managing the capitation funds provided for primary healthcare. Control of cash flow and budget realization is very important in evaluating the use of capitation funds. In addition, the performance points needed by HR in the public healthcare function to add medical services, so the leaders must have a transparent policy in managing the policy points. Intentional factors become difficult conditions to find if they are not analyzed more deeply, so the potential for abuse of authority can still occur. $\frac{36}{-}$

The general operational audit aims to check whether the implementation of an activity that has been carried out is in accordance with what is expected and if there are deviated matters in the audit, the examiner reports the findings to management and provides recommendations for improvement. The management who has a direct interest in the examination must accept each inspection and immediately make the necessary repairs, so that every activity carried out can run effectively and efficiently. $\frac{37}{7}$

Internal audit is very beneficial because it can prevent the occurrence of greater fraud, so that health services can run effectively, efficiently and integrated. FKTP must make clear policies and funds in conducting audits based on positive actions. $\frac{38}{-}$

\section{CONCLUSION}

The potential fraud at the primary healthcare are the management of human resources related to the assessment of performance, skills and personality. Implementation of health services related to facilities and infrastructure, discrimination of JKN participants, work systems and service procedures. Fund management in primary helathcare relates to residual funds and capital funds. The role of leaders in developing audit policies and systems relating to rules and financing.

\section{ACKNOWLEDGMENT}

Thanks to the primary healthcare, especially the responden of primary healthcare from X regency. I would like to extend my gratitude to the campus members and lecturers in this study who haave provide input and assistance in the prosess of this research.

\section{REFERENCE}

1. Kementrian kesehatan R.I. (2013). Standar Tarif Pelayanan Kesehatan pada Fasilitas Kesehatan Tingkat Pertama dan Fasilitas Kesehatan Tingkat Lanjut dalam Penyelenggaraan Program Jaminan Kesehatan, Permenkes Nomor 69. Jakarta.

2. IHPP Thailand. (2011). Universal Health Coverage : Thailand Experience.

3. Maidin A, Palutturi S. (2016) Kajian Implementasi Jaminan Kesehatan Nasional Lintas Provinsi. Makasar :Universitas Hasanundin.

4. Bappenas. (2011). Peningkatan Akses Masyarakat terhadap Kesehatan yang Berkualitas.

5. Efendi, Ferry. (2009) Keperawatan Kesehatan Komunitas: Teori dan Prektek dalam Keperawatan. Jakarta: Salemba Medika.

6. Suhadi Sukri Palutturi, Muh Kardis Rais, Zainuddin, Alimin Maidin. (2014). Fraud Prevention In Implementation In National Health Insurance Kendari City. Indonesia. International Journal of Health and Medical Sciences. Kendal.

7. Kementrian kesehatan R.I. (2014). Standar Tarif Pelayanan Kesehatan Dalam Penyelenggaraaan Program Jaminan Kesehatan. Permenkes Nomor 59. Jakarta.

8. BPJS Kesehatan. Panduan Praktis Gate Keeper Concept Faskes BPJS Kesehatan ; 2015

9. Morris. (2009) Health Insurance: The Journal of Risk and Insurance.

10. Albrecht, W. S., Hill, N. C., \& Albrecht, C. C. (2006). The ethics development model applied to declining ethics in accounting. Australian Accounting Review, 16(1), 30-40

11. R Thanasak. (2013). Beyond the Fraud Diamond. International Journal of Management and Administrative Sciences, 2(1), pp.01-05.

12. Zafirah Rizka, Sutopo Patria Jati, S. B. (2018). Analisis Pencegahan Kecurangan dikota Semarang. Jurnal Kesehatan Masyarakat, 6, 95-104.

13. Wolfe, D., \& D. R. Hermanson. (2004). The fraud diamond: Considering four elements of fraud. The CPA Journal, 74(12), 38-42.

14. Kementrian kesehatan R.I. (2015). Pencegahan Kecurangan (Fraud) Dalam Pelaksanaan Jaminan Sosial Nasional, Permenkes Nomor 36. Jakarta. 
15. KPK. (2015). KPK Temukan 4 Kelemahan Pengelolaan Dana Kapitasi. Retrieved from https://www.kpk.go.id/id/berita/siaran-pers/2440kpk-temukan-4-kelemahan-pengelolaan-dana-kapitasi

16. Rae, K., \& Subramaniam, N. (2008). Quality of internal control procedures: Antecedents and moderating effect on organisational justice and employee fraud. Managerial Auditing Journal, 23(2), 104-124.

17. McClurg, L. A., \& Butler, D. S. (2006). Workplace theft: A proposed model and research agenda. Southern Business Review, 31(2), 25-34

18. Holtfreter, K. (2004). Fraud in U.S. organisations: An examination of control mechanisms. Journal of Financial Crime, 12(1), 88-95.

19. BPJS Kesehatan. (2015). Panduan Praktis Pelayanan Kesehatan. Diakses 25 April 2016, dari http.//www.bpjs-kesehatan.go.id/semuadownload.html.

20. Freshka. (2015). Analisis Kualitas Sumber Daya Manusia dan Pengaruhnya terhadap Pertumbuhan Ekonomi. Pelalawan. Jurnal Jom Fekon Vol.2 No.2.

21. Salamete, Rattu dan Pangemanan. (2014). Analisis Perencanaan Sumber Daya Manusia Kesehatan di Dinas Kesehatan Kabupaten Minahasa Tenggara. Minahasa Tenggara. Jurnal Ilmu Kesehatan Masyarakat Unsrat, Suplemen, Vol.4, No.4.

22. Mas'ud, Fuad. (2004). Survai Diagnosis Organisasional Konsep \& Aplikasi. Badan Penerbit Universitas Dipenogoro. Semarang.

23. Hasan, A. G., \& Adisasmito, W. B. B. (2017). ANALISIS KEBIJAKAN PEMANFAATAN DANA KAPITASI JKN PADA. Jurnal Kebijakan Kesehatan, 6(03), 127-137.

24. Futhoni, Renata Arianingtyas, Siti Aminah, Uli Parulian Sihombing. (2009). Memahami Diskriminasi. Buku Saku Kebebasan Beragama.

25. Liliweri, Alo. (2005). Prasangka \& Konflik: Komunikasi Lintas Budaya Masyarakat Multikultural. Buku Penerbit LKiS.

26. Kementrian kesehatan R.I. (2014) Pusat Kesehatan Masyarakat. Permenkes Nomor 75. Jakarta.

27. Kementrian kesehatan R.I. (2014) Klinik. Permenkes Nomor 9. Jakarta.
28. Dorminey, J., Fleming, A., Kranacher, M., \& Riley, R. (2010). Beyond the fraud triangle. The CPA Journal, 80(7), 17-23.

29. Jackson, K., Holland, D., Albrecht, C., \& Woolstenhulme, D. (2010). Fraud isn't just for big business: Understanding the drivers, consequences, and prevention of fraud in small business. Journal of International Management Studies, 5(1), 160-164.

30. Soleman. (2013) Pengaruh Pengandalian Internal dan Good Coporate Governance terhadap Pencegahan Fraud. JAAI Vol. 17 No.1.

31. Tuanakotta, Theodorus M. (2007). Akuntansi Forensik dan Audit Investigatif. Jakarta : Lembaga Penerbit Fakultas Ekonomi Universitas Indonesia.

32. Presiden R.I. (2014). Pengelolaan Dan Pemanfaatan Dana Kapitasi Jaminan Kesehatan Nasional Pada Fasilitas Kesehatan Tingkat Pertama Milik Pemerintah Daerah. Perpres Nomor 32. Jakarta.

33. Trisnawati, Nugroho dan Wanto. (2014). Pengaruh Implementasi Sistem Pengadaan Secara Elektronik (E-Procurement) terhadap Fraud pengadaan Barang/ jasa Pemerintah. Jurnal Administrasi Publik (JAP), Vol.3 No.1

34. Setiaji, Tomi Kostantia. (2015). Analisis Faktor Internal Dan Eksternal Sebagai Bahan Penyusun Strategi Pencegahan Fraud Dana Kapitasi Puskesmas Di Kota Semarang. Semarang. JKM eJournal FKM Undip, Vol.3 No.3

35. Nasharuddin Baidan\& Erwati Aziz. (2014). Etika islam dalam Berbisnis, Yogyakarta. Pustaka Pelajar. h. 127

36. Fullerton, Rosemary R \& Cindy Durtschi. (2004). The Effect of Professional Skepticism on The Fraud Detection Skills of Internal Auditors. Working Paper Series. Utah State University.

37. Divianto. (2012). Peranan Audit Operasional terhadap Efektivitas Pelayanan Kesehatan Rawat Inap di Rumah Sakit. Jurnal Ekonomi dan Informasi Akuntansi, Vol.2 No.2

38. Wardhini. (2010). Peranan Audit Internal dalam Pencegahan Kecurangan. Skripsi. Sarjana Ekonomi, Universitas Widyatama. 